\title{
Krajowa Administracja Skarbowa w świetle „standardów” stanowionego prawa oraz polityki kadrowo-płacowej - uwagi krytyczne
}

\author{
The National Revenue Administration - critical remarks \\ regarding the "standards" of lawmaking of this \\ institution, as well as its personnel and payroll policy
}

Streszczenie. Przedmiotem rozważań i analiz w artykule jest m.in. ocena procesu legislacyjnego związanego z utworzeniem Krajowej Administracji Skarbowej wraz z następczą pragmatyką kadrowo-płacową w tym obszarze. Przeprowadzone badania wykazały, że reforma rządowej administracji danin publicznoprawnych w zakresie tzw. konsolidacji administracji podatkowej, służby celnej oraz kontroli skarbowej nie została należycie przygotowana. W tym zakresie autor wskazuje główne jej mankamenty, popierając swoje tezy materiałem empirycznym.

Słowa kluczowe: Krajowa Administracja Skarbowa; pracownik; funkcjonariusz; wynagrodzenie; uposażenie; polityka. 


\begin{abstract}
The subject of consideration and analysis in the article is, among others, an assessment of a legislative process related to the creation of the National Revenue Administration, and a subsequent pragmatics relating to its $\mathrm{HR}$ and payroll policy. Studies have shown that a reform of the government administration of public levies in the field of the so-called consolidation of the tax administration, customs service and fiscal control has not been adequately prepared. In this respect, the Author identified main shortcomings of that reform, supporting his views with empirical material.
\end{abstract}

Keywords: the National Revenue Administration; an employee; an officer; a salary; an emolument; a policy.

\title{
1. Uwagi wprowadzające
}

W artykule poddano rozważaniom wybrane aspekty związane z szeroko rozumianym procesem tworzenia prawa podatkowego, polityki kadrowej wraz z systemem wynagrodzeń (uposażeń) na przykładzie funkcjonującej w polskim systemie prawnym od 1 marca 2017 r. Krajowej Administracji Skarbowej. Zarówno dogmatyczna, jak również częściowo historyczna analiza powyższej regulacji prawnej poparta została badaniami empirycznymi przeprowadzonymi na podstawie danych uzyskanych od Ministra Finansów (Ministra Finansów, Inwestycji i Rozwoju / Ministra Finansów, Funduszy i Polityki Regionalnej) począwszy, przez dyrektorów izb administracji skarbowej oraz naczelników urzędów skarbowych i naczelników urzędów celno-skarbowych, na raportach Najwyższej Izby Kontroli kończąc.

Dokonana w nad wyraz błyskawicznym tempie reforma konsolidująca administrację danin publicznoprawnych co do zasady w zakresie przekształcenia jej zadań, jak i struktury organizacyjnej czyni całkowicie zasadnym pytanie badawcze m.in. o jakość, a przede wszystkim o „wizję prawodawcy” w stanowieniu prawa wraz z następstwami kadrowopłacowymi, ale także etycznymi w tym obszarze. 


\section{Wybrane aspekty „techniki legislacyjnej” związane z utworzeniem Krajowej Administracji Skarbowej}

Z dniem 1 marca 2017 r. na podstawie ustawy z dnia 16 listopada 2016 r. o Krajowej Administracji Skarbowej ${ }^{1}$ oraz ustawy z dnia 16 listopada 2016 r. przepisy wprowadzające ustawę o Krajowej Administracji Skarbowej $^{2}$ ustawodawca dokonał tzw. konsolidacji administracji podatkowej, służby celnej i kontroli skarbowej ${ }^{3}$, tworząc Krajową Administrację Skarbową ${ }^{4}$. W nowej strukturze organizacyjnej doszło do tzw. scalenia przedmiotowego departamentów na poziomie centralnym w Ministerstwie Finansów, ale przede wszystkim nastąpiło połączenie podmiotowe na poziomie regionalnym oraz lokalnym izb i urzędów skarbowych, urzędów kontroli skarbowych, izb i urzędów celnych - w izby administracji skarbowej oraz w urzędy skarbowe i urzędy celno-skarbowe ${ }^{5}$. Bez wątpienia co zauważono również $\mathrm{w}$ literaturze przedmiotu ${ }^{6}$ - była to największa $\mathrm{z}$ reform dokonanych $\mathrm{w}$ administracji danin publicznych na przełomie ostatnich kilkudziesięciu lat. Jednakże w tym zakresie warto zwrócić uwagę na co najmniej kilka jej mankamentów.

Po pierwsze, projekty ustaw związanych z Krajową Administracją Skarbową pochodziły od grupy posłów partii mającej większość parla-

Tekst jedn. Dz.U. z 2021 r., poz. 422 ze zm.; dalej: u.KAS.

Dz.U. z 2016 r., poz. 1948 ze zm.; dalej: u.p.w.KAS.

K. Teszner, Customs and Fiscal Control in Poland as a Radical Measure to Eliminate Tax Evasion, „Intertax” 2020, Vol. 48, Issue 10, s. 922.

4 Szerzej: A. Melezini, K. Teszner (red.), Krajowa Administracja Skarbowa. Komentarz, Warszawa 2018; I. Nowak, National Revenue Administration - current organisational and financial problems, „Prawo Budżetowe Państwa i Samorządu” 2020, nr 2, s. 37 i n.; A. Halicki, Służba w służbie celno-skarbowej, Szczecin 2021, s. 17 i n.

5 Pismo Ministra Rozwoju i Finansów z dnia 31 października 2017 r., DKA8.054.14.2017, http://orka2.sejm.gov.pl/INT8.nsf/klucz/658C47F0/\%24FILE/ i16043-o1.pdf (dostęp: 7.03.2021); I. Nowak, M. Dominiak, Krajowa Administracja Skarbowa a uszczelnianie systemu podatkowego - spostrzeżenia po dwóch latach funkcjonowania [w:] P. Łabuz, I. Malinowska, M. Michalski (red.), Przestępczość gospodarcza. System zwalczania. Cz. I, Warszawa 2020, s. 122.

6 J. Kulicki, Koncepcja Krajowej Administracji Skarbowej w świetle problemów administracji danin publicznych w Polsce, „Analizy i Studia CASP” 2016, nr 2, s. 10 i n.; I. Nowak, National..., s. 56. 
mentarną, co bez wątpienia było zabiegiem celowym ${ }^{7}$, ponieważ nie musiały one przejść kompleksowego procesu uzgodnień ${ }^{8}$ wraz ze szczegółową oceną skutków regulacji ${ }^{9}$. W piśmiennictwie zwraca się uwagę, że w Polsce nagminnie w ostatnich latach unika się konsultacji poprzez zgłaszanie projektów poselskich ${ }^{10}$, który są zwolnione z tego trybu ${ }^{11}$. Być może dlatego, że osoby odpowiedzialne za legislację podatkową są przekonane, iż wszystko wiedzą na ten temat, i uważają, że „dobrą ustawę podatkową mogą napisać w ciągu dwóch tygodni”12. A ponadto, politykom, którzy de facto występują w roli legislatorów, w żaden sposób nie przeszkadza m.in. „brak wykształcenia prawniczego, aby być np. ministrem odpowiedzialnym za tworzenie prawa”13. Jednakże „ludzie władzy będący politykami albo urzędnikami powinni być wykonawcami szeroko pojętej służby publicznej (cywilnej), a sprawowanie władzy powinno być

7 Jakość procesu stanowienia prawa w drugim roku rzqdów Prawa i Sprawiedliwości, X Komunikat Obywatelskiego Forum Legislacji o jakości procesu legislacyjnego na podstawie obserwacji w okresie od 16 listopada 2016 do 15 listopada 2017 roku, s. 22, http://obserwatoriumdemokracji.pl/wp-content/uploads/2016/03/Komunikatw\%C5\%82a\%C5\%9Bciwy.pdf (dostęp: 5.03.2021 r.).

8 Analogicznie D.J. Gajewski, A. Nowak-Far, Krajowa Administracja Skarbowa propozycja konsolidacji aparatu skarbowego a uszczelnienie systemu podatkowego, „Analizy i Studia CASP” 2016, nr 2, s. 8.

9 I. Nowak, Funkcjonariusze celni w strukturze Krajowej Administracji Skarbowej uwagi wybrane, „Kwartalnik Prawa Podatkowego” 2019, nr 2, s. 41.

10 Istnieje zatem potrzeba uchwalenia tzw. prawa do dobrego prawodawstwa, zgodnie z którym wszystkie projekty przepisów prawa podatkowego, w tym w szczególności projekty poselskie, są poddawane konsultacjom z udziałem podatników, przedstawicieli organizacji społecznych, samorządowych i gospodarczych oraz samorządów zawodowych - szerzej poselski projekt ustawy - Karta Praw Podatnika z 2019 r., druk nr 3458, (Sejm RP VIII kadencji), https://www.sejm.gov.pl/Sejm8.nsf/druk.xsp?nr=3458 (dostęp: 25.03 .2021 r.); W. Nykiel, M. Sęk, Karta Praw Podatnika - potrzebny instrument ochrony praw polskiego podatnika [w:] P. Borszowski (red.), Regulacje prawa finansów publicznych i prawa podatkowego. Podsumowanie stanu obecnego i dynamika zmian. Księga jubileuszowa dedykowana Profesor Wiesławie Miemiec, Warszawa 2020, s. 466 i n.

11 W. Nykiel, Prawa podatnika a stanowienie prawa podatkowego - wybrane zagadnienia, „Kwartalnik Prawa Podatkowego” 2019, nr 4, s. 12.

12 B. Brzeziński, W. Nykiel, Reforma systemu podatkowego - aspekty prawne, „Przegląd Podatkowy” 2003, nr 6, s. 4.

13 A. Kidyba, Osiem grzechów głównych, „Dziennik Gazeta Prawna” z dnia 16 lutego 2021, nr 31 (5439), s. D2. 
dla nich misją wykonywaną w dobrej wierze. To piękna bajeczka, ale warto o nią zabiegać" 14 .

Po drugie, prace nad projektami ustaw reformujących administrację danin publicznoprawnych prowadzone były de facto w Ministerstwie Finansów ${ }^{15}$ (tzw. resortowe tworzenie prawa podatkowego ${ }^{16}$ lub prawotwórstwo departamentowe ${ }^{17}$ ). Także według raportu Najwyższej Izby Kontroli przedłożone przez parlamentarzystów projekty zawierały unormowania uwzględniające rozwiązania wypracowane w ramach prac prowadzonych w Ministerstwie Finansów ${ }^{18}$. Co ciekawe - i jednoznacznie „dysfunkcyjne” - przedstawiciele Ministerstwa Finansów, a nie autorzy projektów odgrywali dominującą rolę w zakresie uzasadniania projektowanych zmian wraz z udzielaniem odpowiedzi na zadawane pytania ze strony posłów opozycji i zaproszonych gości ${ }^{19}$. Na tym tle także obserwacja „praktyki parlamentarno-gabinetowej” dowodzi, że „oddzielną kwestią jest to, czy projekt zgłoszony jako poselski został rzeczywiście opracowany przez posłów. Wątpliwości rodzą się na przykład wówczas, gdy na posiedzeniu komisji jakiś poseł zadaje pytanie posłowi reprezentującemu wnioskodawców, zapytany milczy, a odpowiada przedstawiciel ministerstwa i taka sytuacja powtarza się wielokrotnie”"20.

Reasumując, powyższy sposób procedowania aktów prawnych z zakresu prawa podatkowego nie odpowiada regułom państwa prawnego,

14 W. Modzelewski, Czy podatnicy, zwłaszcza będqcy przedsiębiorcami, maja (choć trochę) zaufania do prawa podatkowego?, https://gf24.pl/26376/czy-podatnicyzwlaszcza-bedacy-przedsiebiorcami-maja-choc-trochezaufania-do-prawa-podatkowego/ (dostęp: 04.04.2021 r.).

15 Szerzej I. Nowak, Funkcjonariusze..., s. 41.

16 B. Brzeziński, W. Nykiel, Stan prawa podatkowego w Polsce. Raport 2010, „Kwartalnik Prawa Podatkowego" 2011, nr 1, s. 62 i n.

17 B. Brzeziński, W. Nykiel, Reforma..., s. 4.

18 Tamże; zob. także wypowiedzi podsekretarza stanu w Ministerstwie Finansów podczas posiedzenia Komisji Finansów Publicznych z dnia 18 października 2016 r., http://orka.sejm.gov.pl/Zapisy8.nsf/wgskrnr/FPB-116 (dostęp: 2.03.2021 r.).

19 Tamże.

20 W. Nykiel, Prawa..., s. 12. 
zaburzając tym samym transparentność całego procesu legislacyjnego ${ }^{21}$. Innymi słowy, jako jednoznacznie negatywną należy uznać praktykę pisania ustaw przez Ministerstwo Finansów, a następnie przedstawiania ich jako projekty poselskie, ponieważ ta nagminnie stosowana w ostatnich

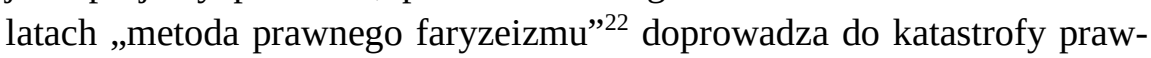
$n^{23}{ }^{23}$. Tym samym „udawanie, jakoby inicjatywa ustawodawcza pochodziła od posłów, podczas gdy tak naprawdę jest to propozycja rządowa”"24 jest niczym innym jak „upolitycznieniem legislacji” poprzez większość parlamentarną ${ }^{25}$ i nolens volens wypaczeniem modelu racjonalnego tworzenia prawa podatkowego ${ }^{26}$.

\section{Pracownicy (funkcjonariusze) Krajowej Administracji Skarbowej w świetle polityki kadrowej}

Z dniem wejścia w życie ustaw o Krajowej Administracji Skarbowej wszyscy pracownicy (funkcjonariusze) administracji podatkowej, służby celnej oraz urzędów kontroli skarbowej stali się pracownikami lub funkcjonariuszami nowo powstałej „instytucji” ${ }^{27}$. W rezultacie tzw. konsolidacji utworzono: 16 izb administracji skarbowej, 16 urzędów celnoskarbowych wraz z 45 delegaturami urzędów celno-skarbowych i 143

21 M. Szwast, Ocena przeprowadzonej reformy zwiqzanej z utworzeniem Krajowej Administracji Skarbowej w świetle zasad tworzenia prawa i ochrony praw pracowniczych, 15 września 2018 r., s. 11.

22 A. Kidyba, Osiem..., s. D3.

23 I. Nowak, Funkcjonariusze..., s. 42.

A. Kidyba, Osiem..., s. D3.

25 Zob. także W. Łączkowski, Wymiar sprawiedliwości a stosowanie prawa [w:] A. Dębiński, A. Grześkowiak, K. Wiak (red.), Ius et lex. Księga pamiqttkowa ku czci prof. Adama Strzembosza, Lublin 2002, s. 53.

26 Zob. A. Gomułowicz, Konstytucyjny aspekt stanowienia obowiq̨zków podatkowych [w:] M. Bogucka (red.), Finanse publiczne a Konstytucja, Warszawa 2020, s. 26-27.

27 Pismo Ministra Rozwoju i Finansów z kwietnia 2017 r., nr AP2.054.3.2017, https://orka2.sejm.gov.pl/INT8.nsf/klucz/658C47EF/\%24FILE/i11106-o1.pdf (dostęp: 10.03.2021 r.). 
oddziałami celnymi oraz zachowano 400 urzędów skarbowych ${ }^{28}$. Tytułem porównania: stan zatrudnienia w administracji danin publicznoprawnych na dzień 30 kwietnia 2016 r. - czyli prawie rok przed wejściem w życie Krajowej Administracji Skarbowej - wynosił 67758 osób, z czego w: Ministerstwie Finansów - 2221; izbach i urzędach skarbowych 45 098; urzędach i izbach celnych - 14987 oraz urzędach kontroli skarbowej - 5452 ${ }^{29}$. Natomiast na dzień 31 maja 2020 r. zatrudnienie w „nowej formule organizacyjnej” administracji podatkowej (skarbowej) liczy 63 202,09 etatów (w Krajowej Administracji Skarbowej - 61 102,0930 plus ok. 2100 pracowników w Ministerstwie Finansów ${ }^{31}$ ). Przykładowo, w podziale na poszczególne Izby Administracji Skarbowej wraz z podległymi urzędami skarbowymi i urzędami celno-skarbowymi na dzień 30 grudnia 2020 r. liczba pracowników korpusu służby cywilnej

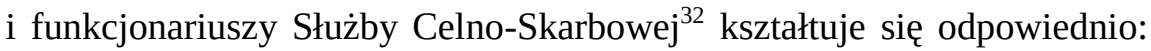
Białystok - 1341 pracowników oraz 1019 funkcjonariuszy S.C-S; Bydgoszcz - 2530 pracowników oraz 254 funkcjonariuszy S.C-S; Gdańsk 2820 pracowników oraz 657 funkcjonariuszy S.C-S; Katowice - 5306

28 Szerzej I. Nowak, M. Dominiak, Krajowa..., s. 111 i n.; pismo Ministra Rozwoju i Finansów z dnia 7 lutego 2017 r., nr RS6.054.3.2017, https://orka2.sejm.gov.pl/ INT8.nsf/klucz/658C47EE/\%24FILE/i09407-o1.pdf (dostęp: 4.03.2021 r.); pismo Ministra Finansów z dnia 23 kwietnia 2018 r., nr DOW6.054.8.2018.KZM, https://orka2.sejm.gov.pl/INT8.nsf/klucz/658C47F2/\%24FILE/i20954-o1.pdf (dostęp: 1.03.2021 r.).

29 Według pisma Ministra Finansów z dnia 9 czerwca 2016 r., nr BDG7.054.3.2016, https://orka2.sejm.gov.pl/INT8.nsf/klucz/323A0944/\%24FILE/i03269-o1.pdf (dostęp: 23.01.2021 r.); I. Nowak, Krajowa Administracja Skarbowa w liczbach, „Kazus Podatkowy” 2020, nr 4, s. 24-25.

30 Pismo Ministra Finansów z dnia 24 czerwca 2020 r., nr DOS11.054.47.2020.KZM, http://orka2.sejm.gov.pl/INT9.nsf/klucz/ATTBQXEQJ/\%24FILE/i07349-o1.pdf (dostęp: 22.02.2021 r.).

31 Wyliczone dane dotyczące stanu zatrudnienie podanego w etatach (nieuwzględniające osób zatrudnionych na umowę zastępstwa oraz przebywających na urlopach bezpłatnych, urlopach związanych) oparte zostały na piśmie Ministra Finansów, Funduszy i Polityki Regionalnej z dnia 14 grudnia 2020 r., nr BMI1.0123.1795.2020, po uprzednim pomniejszeniu pracowników jednostek organizacyjnych Krajowej Administracji Skarbowej zatrudnionych w Ministerstwie Finansów w liczbie 873,750 etatu - vide pismo Ministra Finansów z dnia 24 czerwca 2020 r., nr DOS11.054.47.2020.KZM, http://orka2.sejm.gov.pl/INT9.nsf/klucz/ATTBQXEQJ/\%24FILE/i07349-o1.pdf (dostęp: 5.03.2021 r.).

Dalej: S.C-S. 
pracowników oraz 650 funkcjonariuszy S.C-S; Kielce - 1245 pracowników oraz 135 funkcjonariuszy S.C-S; Kraków - 3881 pracowników oraz 408 funkcjonariuszy S.C-S; Lublin - 2366 pracowników oraz 1731 funkcjonariuszy S.C-S; Łódź - 3334 pracowników oraz 426 funkcjonariuszy S.C-S; Olsztyn - 1504 pracowników oraz 822 funkcjonariuszy S.C-S; Opole - 1464 pracowników oraz 208 funkcjonariuszy S.C-S; Poznań 4381 pracowników oraz 488 funkcjonariuszy S.C-S; Rzeszów - 2138 pracowników oraz 1103 funkcjonariuszy S.C-S; Szczecin - 2507 pracowników oraz 443 funkcjonariuszy S.C-S; Warszawa - 6783 pracowników oraz 1203 funkcjonariuszy S.C-S; Wrocław - 3702 pracowników oraz 455 funkcjonariuszy S.C-S; Zielona Góra - 1401 pracowników oraz 406 funkcjonariuszy S.C-S. ${ }^{33}$. Warto także zauważać, że w Krajowej Administracji Skarbowej pełni służbę 11 kapelanów reprezentujących wyznanie rzymskokatolickie i prawosławne ${ }^{34}$, zatrudnionych na 10,75 etatu ${ }^{35}$.

Z powyższych danych wynika, że po dokonaniu tzw. kreatywnej polityki kadrowej zatrudnienie ogółem w jednostkach Krajowej Administracji Skarbowej nie uległo istotnej zmianie ${ }^{36}$. Jednakże zestawienie kosztów związanych z jej utworzeniem ${ }^{37}$ rozmija się z wymagalnymi obciążeniami budżetu państwa, chociażby z tytułu roszczeń dochodzonych $\mathrm{w}$ ramach

33 Liczba pracowników oraz funkcjonariuszy izb administracji skarbowej wraz z podległymi urzędami skarbowymi i urzędami celno-skarbowymi na dzień 30 listopada 2020 r., z wyłączeniem osób zatrudnionych na umowę zastępstwa oraz przebywających na urlopach bezpłatnych i urlopach związanych z rodzicielstwem - pismo Ministra Finansów, Funduszy i Polityki Regionalnej z dnia 22 grudnia 2020 r., nr BMI1.0123.1882.2020 pozyskane w trybie ustawy o dostępie do informacji publicznej (tekst jedn. Dz.U. z 2020 r., poz. 2176 ze zm.). W przypadku pozostałych pism organów administracji podatkowej, przy których brak będzie informacji o bazie, w której są one dostępne, należy rozumieć, że zostały uzyskane na podstawie powyższego aktu prawnego.

34 Pismo Ministra Finansów, Funduszy i Polityki Regionalnej z dnia 14 grudnia 2020 r., nr BMI1.0123.1795.2020.

35 Pismo Ministra Finansów, Funduszy i Polityki Regionalnej z dnia 2 lutego 2021 r., nr DBM5.054.5.2021, http://orka2.sejm.gov.pl/INT9.nsf/klucz/ATTBXVKDT/\%24FILE/i17694-o1.pdf (dostęp: 9.03.2021 r.).

36 I. Nowak, Funkcjonariusze..., s. 50.

37 Uzasadnienie projektu ustawy o Krajowej Administracji Skarbowej, druk sejmowy nr 826/VIII kadencja, https://www.sejm.gov.pl/Sejm8.nsf/druk.xsp?nr=826 (dostęp: 19.02.2021 r.), dalej: uzasadnienie KAS. 
postępowań sądowych wszczętych przez pracowników i funkcjonariuszy $^{38}$, które mogą wynieść ok. 10 mln zł. ${ }^{39}$.

W ramach tzw. procesu przekształcenia struktury organizacyjnej administracji celno-skarbowej „nie przeprowadzono analizy potrzeb kadrowych, a zastosowana praktyka wygaszania zatrudnienia budzi wątpliwości natury prawnej w zakresie przestrzegania i ochrony praw pracowniczych, głównie przez niewystarczający nadzór Szefa KAS nad procesem kształtowania polityki kadrowej" ${ }^{40}$. W okresie, w którym propozycje pracy/służby miały być składane, stworzono „nieformalny system poufnych rekomendacji (tzw. system poufnego opiniowania, pozwalający ignorować aktualne oceny okresowe i standardy oceniania w służbie publicznej)"41. W rezultacie trudno przyjąć a priori, że dyrektorzy izb administracji skarbowej przy zatrudnianiu pracowników (funkcjonariuszy) kierowali się wyłącznie kompetencjami osób aplikujących ${ }^{42}$. W efekcie konsolidacja administracji podatkowej, kontroli skarbowej i służby celnej została wykorzystana do licznych „zwolnień i przeprowadzenia czystek

38 W okresie od 1 marca 2017 r. do 31 marca 2019 r. do wojewódzkich sądów administracyjnych oraz sądów powszechnych zwolnieni pracownicy (funkcjonariusze) oraz ci, którym obniżono wynagrodzenie, wnieśli przeciwko Dyrektorom Izb Administracji Skarbowej 1161 pozwów - według pisma Ministra Finansów z kwietnia 2019 r., DLK11.054.1.2019,

http://orka2.sejm.gov.pl/INT8.nsf/klucz/ATTBBDDBQ/\%24FILE/i30349-o1.pdf (dostęp: 11.03.2021 r.).

39 Według Dyrektora Departamentu Budżetu, Logistyki i Kadr Krajowej Administracji Skarbowej - informacja Najwyższej Izby Kontroli z dnia 17 grudnia 2019 r. pt. Stan organizacji Krajowej Administracji Skarbowej, nr ewid. 159/2019/P/18/009/KBF, s. 66, https://www.nik.gov.pl/plik/id,21676,vp,24326.pdf (dostęp: 22.02.2021 r.), dalej: Informacja NIK; I. Nowak, Funkcjonariusze..., s. 50.

40 Wystąpienie pokontrolne Najwyższej Izby Kontroli z dnia 21 grudnia 2018 r., nr KBF. 410.005.01.2018, https://www.gov.pl/attachment/8af65bb1-87a1-48da-9a4b-aadbdec001e3 (dostęp: 11.02.2021 r.).

41 M. Piotrowski, Ocena przeprowadzonej reformy zwiqzanej z utworzeniem Krajowej Administracji Skarbowej w świetle zasad tworzenia prawa i ochrony praw pracowniczych, listopad 2018 r., s. 57.

42 I. Nowak, National..., s. 60; por. pismo Ministra Finansów z dnia 19 grudnia 2018 r., BDG7.054.24.2018, http:/orka2.sejm.gov.pl/INT8.nsf/klucz/ATTB7REBW/\%24FILE/i27825-o1.pdf (dostęp: 28.02.2021 r.). 
kadrowych”43, a na tzw. „ucywilnieniu” funkcjonariuszy celnych kończąc $^{44}$. W przypadku 4072 funkcjonariuszy celnych ${ }^{45}$ nastąpiło przekształcenie dotychczasowego ich stosunku służbowego w stosunek pracy na skutek złożenia im sui generis „propozycji nie do odrzucenia” w rodzaju tej składanej przez Dona Corleone (głównego bohatera filmu Ojciec Chrzestny) swoim „partnerom biznesowym”46.

M. Rząsa trafnie wykazał - na przykładzie Izby Administracji Skarbowej w Rzeszowie - że „ucywilnienie” nie miało żadnego sensu, gdyż zaraz po tym procesie ogłoszono w niedługim czasie dwie rekrutacje na ponad 210 funkcjonariuszy, która zakończyła się niepowodzeniem ze względu na małą liczbę odpowiednich kandydatów ${ }^{47}$. Jako kolejny dowód absurdu „ucywilnień” niech posłuży argumentacja Ministra Finansów, Funduszy i Polityki Regionalnej z dnia 10 listopada 2020 r. - w ramach tzw. odwrotu od powyższego, widocznie mylnego, kierunku działań związanych z „ucywilnieniami”48 - który podnosi że „składanie propozycji służby byłym funkcjonariuszom Służby Celnej i Służby Celno-Skarbowej, których stosunek służbowy został przekształcony w stosunek pracy (...) został rozłożony na poszczególne etapy (...). Z uwagi na konieczność właściwego zabezpieczenia terminowej i prawidłowej realizacji ustawowych zadań organizacji oraz kierując się specyfiką poszczególnych jednostek organizacyjnych, liczbą osób zainteresowanych przekształceniem stosunku pracy w stosunek służbowy i posiadanymi wakatami funkcjonariuszy (emerytury, przeniesienia do innych służb), informuję, że ostateczny termin zakończenia omawianego procesu uwarunkowany jest wieloma

43 Szerzej I. Nowak, Funkcjonariusze..., za interpelacją poselską nr 30349 J. Cichonia do Ministra Finansów w sprawie reformy administracji skarbowej, http://www.sejm.gov.pl/ Sejm8.nsf/InterpelacjaTresc.xsp?key=BAPKA7 (dostęp: 9.03.2021 r.).

44 Szerzej I. Nowak, Funkcjonariusze..., s. 37 i n.

45 Informacja NIK, s. 47-51.

46 Szerzej I. Nowak, Funkcjonariusze..., s. 45.

47 Interpelacja poselska nr 33509 do Ministra Finansów w sprawie niezrozumiałej, niezgodnej z linią orzeczniczą NSA polityki kadrowej w ramach KAS, czego konsekwencją jest m.in. nielogiczna rezygnacja z funkcjonariuszy IAS Rzeszów prowadząca do osłabienia wschodniej granicy Polski, a zarazem Unii Europejskiej, http://www.sejm.gov.pl/sejm8.nsf/InterpelacjaTresc.xsp?key=BFVDYR\&view=6 (dostęp: 19.02.2021 r.).

48 Analogicznie A. Halicki, Służba..., s. 34 i 293. 
czynnikami, przez co niezbędne jest uwzględnienie jego realizacji w wydłużonym czasie”49. Także według T. Ludwińskiego od jakiegoś czasu zauważalny jest powyższy „trend”, zgodnie z którym nowym pracownikom proponuje się mundur, ponieważ wtedy ich uposażenie jest o wiele większe niż członków korpusu służby cywilnej, pomimo że podczas kontroli wykonują prawie identyczne czynności ${ }^{50}$.

Nota bene z dniem 31 sierpnia 2017 r. wygasały stosunki służbowe ${ }^{51}$ - będących od dnia 1 marca 2017 r. z mocy prawa - funkcjonariuszy Służby Celno-Skarbowej, jeżeli do 31 maja 2017 r. nie otrzymali oni propozycji pełnienia służby albo zatrudnienia oraz tych, którzy odmówili przyjęcia takiej „oferty”52. Wówczas funkcjonariusze Służby Celno-Skarbowej powinni otrzymać decyzję administracyjną zwalniającą ich ze służby, od której zgodnie z art. 276 ust. 2 u.KAS, mogliby w terminie 14 dni złożyć odwołanie do Szefa Krajowej Administracji Skarbowej. Bez wątpienia wydanie takiego indywidualnego aktu administracyjnego gwarantowałoby funkcjonariuszowi prawo do sądowej kontroli prawidłowości i zasadności rozwiązania stosunku służbowego ${ }^{53}$. W tym miejscu należy przypomnieć, że stosunek służbowy funkcjonariusza nawiązuje się na podstawie mianowania (tzw. stosunek o charakterze administracyjnoprawnym), który charakteryzuje, z jednej strony - pewne ograniczenie praw, dyspozycyjność, hierarchiczne podporządkowanie oraz nadrzędność interesu służby nad interesem jednostkowym funkcjonariusza, z drugiej jednak strony - cechuje go prawo do szeregu dodatkowych uprawnień i większa trwałość niż stosunek pracy, regulowany przepisami Kodeksu

49 Pismo Minister Finansów, Funduszy i Polityki Regionalnej z dnia 10 listopada 2020 r., nr DOM5.054.1.2020.KZM, http://orka2.sejm.gov.pl/INT9.nsf/klucz/ATTBVBEUQ/ \%24FILE/z01807-o1.pdf (dostęp: 11.03.2021 r.).

50 T. Ludwiński [w:] A. Radwan, Urzędnik w mundurze wciqż zarabia więcej, „Dziennik Gazeta Prawna” z dnia 25 lutego 2021 r., nr 38 (5446), s. B7.

51 Zgodnie $\mathrm{z}$ art. 170 ust. 3 u.p.w.KAS. było to zwolnienie ze służby.

52 Uchwała SN z dnia 19 lutego 2020 r., III PZP 7/19, LEX/el.

53 Wyrok NSA z dnia 12 listopada 2019 r., I OSK 1330/19, CBOSA; wyrok NSA z dnia 23 października 2019 r., I OSK 1038/19, CBOSA; wyrok WSA w Opolu z dnia 26 września 2019 r., II SAB/Op 56/19, CBOSA; wyrok WSA w Opolu z dnia 26 lutego 2019 r., II SAB/Op 3/19, CBOSA; wyrok WSA w Opolu z dnia 18 grudnia 2018 r., II SAB/Op 92/18, CBOSA. 
pracy $^{54}$. Niestety, dyrektorzy izb administracji skarbowej w Polsce „inaczej” zinterpretowali przepisy w tym zakresie i nie wydawali funkcjonariuszom Służby Celno-Skarbowej decyzji administracyjnych stwierdzających zwolnienie ich ze służby, dopuszczając się w tym stanie bezczynności. Także według orzecznictwa niewydanie przez dyrektorów izb administracji skarbowej decyzji stwierdzającej wygaśnięcie stosunku służbowego funkcjonariusza pomimo istnienia po stronie organu takiego obowiązku skutkować musiało uznaniem, że ten ostatni pozostaje w bezczynności w zakresie załatwienia sprawy ${ }^{55}$. Dopiero w ramach tzw. skarg na bezczynność, składanych do sądów administracyjnych przez funkcjonariuszy Służby Celno-Skarbowej, otrzymywali oni decyzje administracyjne, od których mogli złożyć stosowane środki zaskarżenia.

In minus należy ocenić także trwającą co najmniej kilka lat praktykę polegającą na oddelegowywaniu zarówno czynnych, jak i emerytowanych funkcjonariuszy służb mundurowych (Policji, Agencji Bezpieczeństwa Wewnętrznego, Centralnego Biura Śledczego Policji, Centralnego Biura Antykorupcyjnego itp.) na kierownicze stanowiska w strukturach zarówno Krajowej Administracji Skarbowej ${ }^{56}$, jak i Ministerstwa Finansów w trybie pozakonkursowym i poza wszelkim oficjalnym naborem ${ }^{57}$. „Mechanizm postępowania jest taki sam od lat: albo ludzie ze służb przychodzą do pracy w administracji skarbowej, obecnie - Krajowej Administracji Skarbowej - w ramach oddelegowania, pracując na swoją wyższą, przyszłą emeryturę, ponieważ wynagrodzenie w administracji publicznej jest wyższe niż w służbach, albo zatrudniają się w skarbówce zaraz po

\footnotetext{
Uchwała NSA z dnia 1 lipca 2019 r., I OPS 1/19, CBOSA.

55 Wyrok NSA z dnia 23 października 2019 r., I OSK 1038/19, CBOSA; wyrok WSA w Opolu z dnia 18 grudnia 2018 r., II SAB/Op 92/18, CBOSA.

56 „Żona komendanta CBŚP, z doświadczeniem w banku, została głównym ekspertem skarbowym w wyspecjalizowanej komórce. Jej szefem (Naczelnik Mazowieckiego Urzędu Celno-Skarbowego w Warszawie - przypis autora) jest były podwładny męża (Komendant Centralnego Biura Śledczego Policji - przypis autora)" - szerzej I. Kacprzak, G. Zawadka, Jak żona komendanta CBŚP została głównym ekspertem skarbowym, https://www.rp.pl/Spoleczenstwo/311029933-Jak-zona-komendanta-CBSP-zostalaglownym-ekspertem-skarbowym.html (dostęp: 14.03.2021 r.).

57 Tak T. Ludwiński [w:] G.J. Leśniak, Służby w administracji - sposób na wyższq emeryturę, https://www.prawo.pl/kadry/funkcjonariusze-sluzb-oddelegowani-albo-emerytowanizajmuja,506164.html (dostęp: 15.03.2021 r.).
} 
otrzymaniu emerytury mundurowej. W efekcie ci ostatni otrzymują jednocześnie emeryturę i wynagrodzenie w administracji”58. Jak trafnie zauważył P. Cybulski - w latach 2017-2019 podsekretarz stanu w Ministerstwie Finansów i zastępca Szef Krajowej Administracji Skarbowej - niepokojąca jest tendencja „obsadzania coraz częściej stanowisk do tej pory właściwych pracownikom cywilnym przez funkcjonariuszy. To rodzi niepotrzebne emocje, nieporozumienia i pytania o właściwe kompetencje”59.

Co do kwestii polityki kadrowej, postulaty Szefa (a może trafniej Szefowej) Krajowej Administracji Skarbowej zakładające m.in. chęć pozyskania najbardziej wartościowych kandydatów, w tym z najmłodszego pokolenia, którzy podejmą się nowych wyzwań w budowaniu nowoczesnych struktur Krajowej Administracji Skarbowej; dbanie o kadry poprzez budowę nowoczesnego podejścia opartego na partnerstwie strategicznym; wdrożenie programu wspierającego pracowników i funkcjonariuszy przez całą ścieżkę zawodową - od naboru do przejścia na emeryturę - w tym także program mentorski zachęcający doświadczonych członków zespołu do pozostania w szeregach Krajowej Administracji Skarbowej i przekazywania wiedzy młodszym kolegom - brzmią co do zasady jak propagandowe frazesy korporacyjne ${ }^{60}$. Niestety, w podobnym duchu wypowiada się także Dyrektor Generalna w Ministerstwie Finansów - podczas podpisywania umowę o współpracy pomiędzy Ministerstwem Finansów a Szkołą Główną Handlową - podnosząc m.in., że „łączy nas również idea odczarowania administracji i wspólnego budowania pozytywnego myślenia o niej. Przed nami coraz więcej wyzwań. Silny zastrzyk pozytywnej energii i wiedzy, młodości i doświadczenia to impuls, który jest niezbędny dla stworzenia administracji publicznej przyszłości”61. Chciałoby się zapytać, czy osoby deklarujące powyższe slogany w nie naprawdę wierzą?

58 Tamże.

59 W. Dróżdż, Jak i po co powstała Krajowa Administracja Skarbowa? W czym pomaga przedsiębiorcom?, https://opoka.news/jak-i-po-co-powstala-krajowa-administracjaskarbowa-w-czym-pomaga-przedsiebiorcom (dostęp: 6.05.2021 r.).

60 List Szefa KAS, https://celnicy.pl/threads/list-szefa-kas.16798/ (dostęp: 11.03.2021 r.); pismo Szefa KAS, https://celnicy.pl/threads/informacja-szefa-kas-do-pracownikow-ifunkcjonariuszy.16853/ (dostęp: 12.03.2021 r.).

61 https:/www.gov.pl/web/finanse/jeszcze-blizsza-wspolpraca-miedzy-mf-i-sgh (dostęp: 5.03.2021 r.). 
Już sama obserwacja chociażby permanentnych w ostatnich latach zmian na stanowisku Ministra Finansów, Szefów Krajowej Administracji Skarbowej, podsekretarzy stanów, dyrektorów departamentów oraz ich zastępców ${ }^{62}$ sprawia, że bardzo trudno jest uwierzyć w powyższe zapewnienia ${ }^{63}$. Trafność powyższych spostrzeżeń autora niniejszej publikacji - jak się wydaje - potwierdza P. Cybulski, podkreślając, że ,jednak teraz po odejściu tak wielu dobrych i doświadczonych fachowców z KAS widać, że sam system informatyczny nie będzie w stanie wiele pomóc, jeśli nie będzie odpowiedniej kadry czy odpowiedniej współpracy z osobami merytorycznymi w skarbowości. Na początku i na końcu każdego procesu jest człowiek i to od niego tak naprawdę zależy jakość i skuteczność działania. Dlatego moim życzeniem jako współtwórcy KAS jest, aby jego kierownictwo dostrzegło wartości płynące z kapitału ludzkiego i zatrzymało w organizacji tylko wysoce merytorycznych pracowników i funkcjonariuszy, bo od ich decyzji jest zależny zarówno biznes, jak i budżet państwa”64

Także „sposób współpracy” zarówno ze strony przedstawicieli Krajowej Administracji Skarbowej, jak i Ministerstwa Finansów ze związkami zawodowymi działającymi w tych strukturach organizacyjnych pozostawia wiele do życzenia. Przykładowo S. Siwy (Przewodniczący Związku Zawodowego Celnicy PL) nie otrzymał propozycji pełnienia służby ani też propozycji pracy w nowoutworzonych strukturach Krajowej Administracji Skarbowej ${ }^{65}$. Według uzasadnienia decyzji skierowanej do S. Siwego „Dyrektor Izby Administracji Skarbowej w Opolu, kierując się przede wszystkim prawidłowym funkcjonowaniem oraz wizerunkiem administracji celno-skarbowej oraz rzetelnej realizacji obowiązków wynikających z pełnienia służby przez funkcjonariuszy, nie złożył Panu Sławomirowi Siwemu propozycji pełnienia służby ani zatrudnienia. Odpowiednie znaczenie dla prawidłowości funkcjonowania aparatu celno-

62 Zob. B. Godusławki, Exodus z Ministerstwa Finansów, „Dziennik Gazeta Prawna” z dnia 9 marca 2020 r., nr 47 (5200), s. A12.

63 Szerzej I. Nowak, National..., s. 61.

64 W. Dróżdż, Jak...

65 Zob. decyzja Dyrektora IAS w Opolu z dnia 27 marca 2020 r., nr 1601-IZK.111. 380.2020, https://celnicy.pl/attachments/decyzjaszefa-kas-s-siwy-pdf.7859 (dostęp: 8.03.2021 r.). 
skarbowego ma również zachowanie równowagi i właściwej atmosfery w miejscu pełnienia służby czy wykonywania pracy. Chcąc zatem uniknąć ewentualnych przyszłych konfliktów wewnątrz organizacji, wynikających $\mathrm{z}$ arogancji i pretensjonalnego zachowania Pana Sławomira Siwego, podjęto stosowne w opinii Dyrektora Izby Administracji Skarbowej rozstrzygnięcie”66. Powyższe „działania” S. Siwy odczytuje jednoznacznie - jako „rodzaj kary za krytykę reformy KAS”67. Niestety, uzasadnienie powyższego rozstrzygnięcia, podjętego przez monokratyczny organ podatkowy w Opolu, przypomina analogiczną argumentację z 2012 r. w sprawie innego działacza związkowego - T. Ludwińskiego ${ }^{68}$, który 25 lipca 2012 r. został odwołany ${ }^{69}$ ze stanowiska inspektora kontroli skarbowej, na podstawie art. 42a ust. 1 pkt $3^{70}$ nieobowiązującej obecnie ustawy z dnia 28 września 1991 r. o kontroli skarbowej ${ }^{71}$, m.in. dlatego, że „z racji pełnionych funkcji związkowych bardzo często wypowiada się na temat organizacji pracy Urzędu Kontroli Skarbowej w Warszawie, jego kierownictwa oraz kierownictwa resortu finansów. Zarówno w korespondencji kierowanej do Urzędu, w tym imiennie do Dyrektora Urzędu, jak i w drodze wy-

66 Tamże.

67 M. Kośka, Napięta sytuacja w KAS. Celnicy rozważajq protest, https://www.money.pl/gospodarka/napieta-sytuacja-w-kas-celnicy-rozwazaja-protest6606403507993280a.html (dostęp: 11.03.2021 r.).

68 Przewodniczący Rady Sekcji Krajowej Pracowników Skarbowych NSZZ „Solidarność”; przewodniczący Organizacji Międzyzakładowej NSZZ „Solidarność” Pracowników Skarbowych Województwa Mazowieckiego oraz jednocześnie społeczny zakładowy inspektor pracy w Urzędzie Kontroli Skarbowej w Warszawie http://www.skarbowcy.pl/blaster/print.php?mod=extarticle\&article_id=13866, http://www.skarbowcy.pl/blaster/print.php?mod=extarticle\&article_id=13870 (dostęp: 15.03.2021 r.).

69 Odwołanie z dnia 25 lipca 2012 r., nr KS1/1141/90/BKS/2012/, podpisane przez A. Parafianowicza, Podsekretarza Stanu w Ministerstwie Finansów, Generalnego Inspektora Kontroli Skarbowej, https://www.skarbowcy.pl/blaster/extarticle.php?show =article\&article_id=13872 (dostęp: 7.03.2021 r.).

70 Zgodnie z którym: Generalny Inspektor Kontroli Skarbowej może odwołać inspektora z zajmowanego stanowiska w przypadku ciężkiego naruszenia podstawowych obowiązków członka korpusu służby cywilnej, jeżeli wina inspektora jest oczywista. Wówczas na podstawie art. 42a ust. 2 pkt 2 u.k.s. odwołanie było równoznaczne z rozwiązaniem stosunku pracy bez wypowiedzenia.

71 Ustawa z dnia 28 września 1991 r. o kontroli skarbowej (tekst jedn. Dz.U. z 2011 r., Nr 41, poz. 214 ze zm.), dalej: u.k.s. 
powiedzi na forum internetowym prowadzonym na stronie internetowej Rady Sekcji Krajowej Pracowników Skarbowych NSZZ Solidarność «www.skarbowcy.pl», posługuje się wyrażeniami dalece wykraczającymi poza obowiązujące członka korpusu służby cywilnej granice dozwolonej krytyki oraz właściwe formy wyrażania swojego stanowiska. Podobnie wypowiadając się o kierownictwie Ministerstwa Finansów, używał słów wyrażających treść obraźliwą i zniesławiającą, a więc przedstawioną w niewłaściwej formie krytykę”72. Na zakończenie tejże „smutnej historii” warto jednak podkreślić, że 22 grudnia 2014 r. Sąd Okręgowy w Warszawie (XXI Wydział Pracy) przywrócił T. Ludwińskiego do pracy, wskazując m.in., że nie ma wątpliwości, iż został on usunięty z pracy za działalność związkową $^{73}$, a nie za rzekome naruszenie obowiązków pracowniczych ${ }^{74}$.

Reasumując, czas najwyższy, aby przedstawiciele organów administracji publicznej, związani z szeroko rozumianą administracją danin publicznoprawnych, skończyli raz na zawsze ze stosowaniem maksymy, według której „,by człowiek był człowieka bratem, trzeba go wpierw przećwiczyć batem”75. Autor niniejszej publikacji zachęca wszystkich kierow-

72 Wniosek A. Oszmiańczuka, Dyrektora Urzędu Kontroli Skarbowej w Warszawie z dnia 21 czerwca 2012 r., nr UKS1491/D/074/11/12/1/999, skierowany do Zarządu Komisji Międzyzakładowej Organizacja NSZZ „Solidarność” Pracowników Skarbowych Województwa Mazowieckiego, o zgodę na zwolnienie http://www.skarbowcy.pl/blaster/print.php?mod=extarticle\&article_id=13870 (dostęp: 10.05.2021 r.).

73 „Prawo do takiej krytyki jest ustawowo zagwarantowane i co do zasady wpisane w działalność związkową” - z uzasadnienia ustnego wyroku Sądu Okręgowego w Warszawie z dnia 22 grudnia 2012 r. - K. Batko-Tołuć, Warto stać po właściwej stronie, https://informacjapubliczna.org/news/warto-stac-po-wlasciwej-stronie/ (dostęp: 10.05.2021 r.).

74 Naruszenie przez pracodawcę przepisów o rozwiązaniu umowy o pracę bez wypowiedzenia „było de facto poczwórne, skoro pracodawca w przypadku powoda będącego jednocześnie szczególnie chronionym działaczem związkowym, Społecznym Zakładowym Inspektorem Pracy (art. 13 ust. 1 ustawy z dnia 24 czerwca 1983 r. o społecznej inspekcji pracy) zignorował zarówno brak zgody na to rozwiązanie ze strony zarządu zakładowej organizacji związkowej, we wniosku wskazał jedynie część okoliczności $(\ldots)$ - jak i to, że pracodawca rozwiązał z powodem umowę o pracę z naruszeniem terminu określonego w art. 42a ust. 3 ustawy o kontroli skarbowej" - fragment uzasadnienia wyroku Sądu Okręgowego w Warszawie z dnia 22 grudnia 2014 r., sygn. akt XXI Pa 136/14.

75 J. Szpotański, Gnom. Caryca. Szmaciak, Łomianki 2014, s. 172. 
ników jednostek organizacyjnych związanych z administracją podatkową (skarbową), aby stosując normy prawne $\mathrm{z}$ zakresu prawa pracy oraz pragmatyk służbowych, pamiętali o normach moralnych ${ }^{76}$, a także praktykowali chrześcijańską regułę, zgodnie z którą „wszystko więc, co chcecie, aby wam ludzie czynili, i wy im czyńcie»77. A wtedy już nie trzeba będzie mnożyć demagogicznych haseł w stylu „tworzenia angażującego środowiska pracy i budowy marki atrakcyjnego pracodawcy” do kolejnych kierunków działania i rozwoju Krajowej Administracji Skarbowej ${ }^{78}$.

\section{Wynagrodzenie członków korpusu służby cywilnej a uposażenie funkcjonariuszy Służby Celno-Skarbowej}

Kolejną „bolączką” Krajowej Administracji Skarbowej, oprócz braku jakiejkolwiek „ścieżki zawodowej”79 dla członków korpusu służby cywilnej oraz funkcjonariuszy Służby Celno-Skarbowej, jest „dysfunkcyjny” system ich wynagrodzeń (uposażeń). Stanowisko to potwierdza również P. Cybulski ${ }^{80}$ - jak sam o sobie mówi, „współtwórca KAS”, zauważając m.in. wadliwe „rozwiązania kwestii dysproporcji pomiędzy funkcjonariuszami a pracownikami cywilnymi w zakresie ich wynagradzania”81. Przykładowo, na dzień 31 grudnia 2020 r., porównując uposażenia łączne ${ }^{82}$ brutto funkcjonariuszy Służby Celno-Skarbowej względem wynagrodzeń

76 Szerzej na ten temat W. Łączkowski, Prawo naturalne a prawo stanowione. Uwagi prawnika, „Ethos” 1999, nr 1-2, s. 173 i n.

77 Ewangelia Mateusza 7.12 [w:] Uwspółcześniona Biblia Gdańska, http://bibliaonline.pl/Porownaj/Wersety/Warszawska/Ewangelia-Mateusza/7/12 (dostęp: 11.03.2020 r.).

78 Zarządzenie Ministra Finansów, Funduszy i Polityki Regionalnej z dnia 23 grudnia 2020 r. w sprawie określenia Kierunków działania i rozwoju Krajowej Administracji Skarbowej na lata 2021-2024, Dz.Urz. MFFiPR z 2020 r., poz. 34.

79 https://www.prawo.pl/kadry/funkcjonariusze-sluzb-oddelegowani-albo-emerytowanizajmuja,506164.html.

80 W. Dróżdż, Jak...

81 Tamże.

82 Co do zasady: uposażenie zasadnicze, dodatek za stopień służbowy, dodatek za wieloletnią służbę, dodatek funkcyjny, dodatek za opiekę nad psem służbowym, dodatek specjalny, dodatek kontrolerski, uposażenie za służbę w godzinach nadliczbowych. 
łącznych ${ }^{83}$ brutto członków korpusu służby cywilnej w wybranych izbach administracji skarbowej, już prima facie widać znaczne ich dysproporcje, dochodzące do prawie $30 \%$ na korzyść funkcjonariuszy ${ }^{84}$, np.:

a) IAS w Bydgoszczy: 6196,34 zł / 3337,70 zł (mediana/dominanta) do 5559,44 zł / 5437,52 zł (mediana/dominanta) ${ }^{85}$;

b) IAS w Gdańsku: 6450,30 zł / 6302,10 zł (mediana/dominanta) do 5816,30 zł / 4437,90 zł (mediana/dominanta) ${ }^{86}$;

c) IAS w Katowicach: 6339,35 zł / 6115,10 zł (mediana/dominanta) do 5596,02 zł / 5596,02 zł (mediana/dominanta) ${ }^{87}$;

d) IAS w Kielcach: 6005,17 zł / 5587,10 zł (mediana/dominanta) do 5513,11 zł / 3271,46 zł (mediana/dominanta) ${ }^{88}$;

e) IAS w Łodzi: 6065,98 zł / 6037,10 zł (mediana/dominanta) do 5337,20 zł / 3832,28 zł (mediana/dominanta) ${ }^{89}$;

f) IAS w Szczecinie: 6426,14 zł / 5749,10 zł (mediana/dominanta) do 5747,20 zł / 3799,77 zł (mediana/dominanta) ${ }^{90}$.

g) IAS w Warszawie: 6866,84 zł / 6321,03 zł (mediana/dominanta) do 5786,21 zł / 3639,24 zł (mediana/dominanta) ${ }^{91}$.

Analogiczne różnice łącznych uposażeń brutto występują także wśród samych funkcjonariuszy Służby Celno-Skarbowej w zależności od

83 Co do zasady: wynagrodzenie zasadnicze, dodatek za wieloletnią pracę w służbie cywilnej, dodatek służby cywilnej z tytułu posiadanego stopnia służbowego, dodatek funkcyjny, dodatek kontrolerski i orzeczniczy, dodatek zadaniowy, dodatek wyrównawczy, dodatek urzędnika służby cywilnej.

T. Ludwiński, [w:] A. Radwan, Urzędnik w mundurze wciq̨ż zarabia więcej, „Dziennik Gazeta Prawna” z dnia 25 lutego 2021 r., nr 38 (5446), s. B7. Pamiętać jednocześnie należy, że od uposażenia funkcjonariuszy Służby Celno-Skarbowej nie są pobierane składki na ubezpieczenie emerytalno-rentowe, przez co jest ono wyższe o ok. 12 proc. netto względem członków korpusu służby cywilnej - tak T. Ludwiński [w:] G.J. Leśniak, Służby...

85 Pismo Dyrektora IAS w Bydgoszczy z dnia 18 stycznia 2021 r., nr 0401-IWK.0150. 1.2020.2.

86 Pismo Dyrektora IAS w Gdańsku z dnia 18 stycznia 2021 r., nr 2201-IWK.0150.1.2021.

87 Pismo Dyrektora IAS w Katowicach z dnia 15 stycznia 2021 r., nr 2401-IWK.0150. 2.2021.3.

88 Pismo Dyrektora IAS w Kielcach z dnia 15 stycznia 2021 r., nr 2601-IWK.0150.1.2021.

89 Pismo Dyrektora IAS w Łodzi z dnia 14 stycznia 2021 r., nr 1001-IWK.0150.3.2021.

90 Pismo Dyrektora IAS w Szczecinie z dnia 18 stycznia 2021 r., nr 3201-IWK.0150.4.2021.2.

91 Pismo Dyrektora IAS w Warszawie z dnia 18 stycznia 2021 r., nr 1401-IWK2.0150.4.2021. 
izb administracji skarbowej, w których pełnią służbę. Przykładowo, w: IAS w Lublinie: 5539,84 zł / 3637,70 zł (mediana/dominanta) ${ }^{92}$; IAS w Rzeszowie: 5637,81 zł / 3372,00 zł (mediana/dominanta) ${ }^{93}$. Natomiast już w innych izbach administracji skarbowej te wartości są znacznie wyższe, np. w IAS we Wrocławiu: 8169,60 zł / 8536,98 zł (mediana/dominanta) ${ }^{94}$ czy też w IAS w Zielonej Górze: 8194,72 zł / 7470,00 zł (mediana/dominanta) ${ }^{95}$.

Porównywalna sytuacja występuje także na gruncie łącznego wynagrodzenia brutto członków korpusu służby cywilnej. Przykładowo: IAS w Poznaniu ${ }^{96}$ : 5314,69 zł / 3954,19 zł (mediana/dominanta); IAS w Rzeszowie: 5305,85 zł / 3271,46 zł (mediana/dominanta) ${ }^{97}$. Natomiast już w innych izbach administracji skarbowej te wartości są znacznie większe, np.: w IAS we Wrocławiu ${ }^{98}$ : 7491,66 zł / 7396,57 zł (mediana/dominanta) czy też w IAS w Zielonej Górze: 6902,62 zł / 6340,00 zł (mediana/dominanta $)^{99}$.

Uposażenia funkcjonariuszy Służby Celno-Skarbowej pełniących służbę w Ministerstwie Finansów, na 31 grudnia 2020 r., wynosiły odpowiednio: 7288,51 zł / 7629,07 zł (mediana/średnia) ${ }^{100}$. W przypadku wy-

92 Pismo Dyrektora IAS w Lublinie z dnia 15 stycznia 2021 r., nr 0601-IWK.0150.1. 2021.3.

93 Pismo Dyrektora IAS w Rzeszowie z dnia 15 stycznia 2021 r., nr 1801-IWK.0150. 1.2021.

94 Pismo Dyrektora IAS we Wrocławiu z dnia 18 stycznia 2021 r., nr 0201-IWK.0150. 2.2021 .

95 Pismo Dyrektora IAS w Zielonej Górze z dnia 29 stycznia 2021 r., nr 0801-IWK.0150. 2.2021.

96 Pismo Dyrektora IAS w Poznaniu z dnia 18 stycznia 2021 r., nr 3001-IWK.0150.1.2021.

97 Pismo Dyrektora IAS w Rzeszowie z dnia 15 stycznia 2021 r., nr 1801-IWK.0150. 1.2021.

98 Pismo Dyrektora IAS we Wrocławiu z dnia 8 stycznia 2021 r., nr 0201-IWK.0150. 2.2021.

99 Pismo Dyrektora IAS w Zielonej Górze z dnia 29 stycznia 2021 r., nr 0801-IWK.0150. 2.2021.

100 Przy wyliczaniu powyższych danych uwzględniono następujące składniki: uposażenie zasadnicze oraz dodatki (za stopień służbowy, funkcyjny, za wieloletnią służbę, specjalny, kontrolerski). W zakresie dominanty wykazano jedynie dane obrazujące, w którym przedziale kwotowym największej grupy funkcjonariusz kształtuje się uposażenie (przedział kwotowy 7001-8000 zł dla 74 funkcjonariuszy Służby Celno-Skarbowej) - 
nagrodzeń członków korpusu służby cywilnej zatrudnionych w Ministerstwie Finansów na 31 grudnia 2020 roku, w przeliczeniu na pełny etat, kształtują się następująco: 7802,72 zł (mediana); 7315,06 zł (dominanta) / 8547,99 zł (średnia łącznych wynagrodzeń) ${ }^{101}$.

Tabela 1. Wynagrodzenie brutto PLN członków korpusu służby cywilnej (stan na 31 grudnia 2020 r.).

\begin{tabular}{|l|c|c|c|}
\hline $\begin{array}{c}\text { Izba Administracji } \\
\text { Skarbowej }\end{array}$ & Średnia & Mediana & Dominanta \\
\hline Białystok & 6027,58 & 5499,91 & 3657,53 \\
\hline Bydgoszcz & 6163,24 & 5559,44 & 5437,52 \\
\hline Gdańsk & 6095,40 & 5816,30 & 4437,90 \\
\hline Katowice & 5895,75 & 5596,02 & 5596,02 \\
\hline Kielce & 5750,78 & 5513,11 & 3271,46 \\
\hline Kraków & 6085,42 & 5566,30 & 5235,14 \\
\hline Lublin & 5674,76 & 5309,52 & 5366,81 \\
\hline Łódź & 5691,93 & 5337,20 & 3832,28 \\
\hline Olsztyn & 6721,85 & 6493,76 & 5091,27 \\
\hline Opole & 6180,15 & 5812,18 & 3820,08 \\
\hline Poznań & 5707,97 & 5314,69 & 3954,19 \\
\hline Rzeszów & 5649,40 & 5305,85 & 3271,46 \\
\hline Szczecin & 6218,81 & 5747,20 & 3799,77 \\
\hline Warszawa & 6147,49 & 5786,21 & 3639,24 \\
\hline Wrocław & 7558,97 & 7491,66 & 7396,57 \\
\hline Zielona Góra & 6871,08 & 6902,62 & 6340,00 \\
\hline
\end{tabular}

Źródło: Opracowanie własne na podstawie danych uzyskanych od dyrektorów izb administracji skarbowej w trybie ustawy o dostępie do informacji publicznej przez T. Ludwińskiego (Przewodniczącego Rady Krajowej Sekcji Administracji Skarbowej NSZZ „Solidarność”).

pismo Ministra Finansów, Funduszy i Polityki Regionalnej z dnia 8 lutego 2021 r., nr BMI1.0123.147.2021.

101 Tamże. 
Tabela 2. Wynagrodzenie brutto funkcjonariuszy Służby Celno-Skarbowej (stan na 31 grudnia $2020 \mathrm{r}$.

\begin{tabular}{|l|c|c|c|}
\hline $\begin{array}{c}\text { Izba Administracji } \\
\text { Skarbowej }\end{array}$ & Średnia & Mediana & Dominanta \\
\hline Białystok & 5869,51 & 5716,42 & 3598,30 \\
\hline Bydgoszcz & 6318,50 & 6196,34 & 3337,70 \\
\hline Gdańsk & 6680,00 & 6450,30 & 6302,10 \\
\hline Katowice & 6336,48 & 6339,35 & 6115,10 \\
\hline Kielce & 5970,90 & 6005,17 & 5587,10 \\
\hline Kraków & 6411,06 & 6431,23 & 3766,90 \\
\hline Lublin & 5569,81 & 5539,84 & 3637,70 \\
\hline Łódź & 6269,31 & 6065,98 & 6037,10 \\
\hline Olsztyn & 6462,44 & 6523,23 & 3666,70 \\
\hline Opole & 7255,50 & 7489,60 & 5536,10 \\
\hline Poznań & 6064,25 & 5907,58 & 5959,10 \\
\hline Rzeszów & 5681,48 & 5637,81 & 3372,00 \\
\hline Szczecin & 6218,83 & 6426,14 & 5749,10 \\
\hline Warszawa & 7004,64 & 6866,84 & 6321,03 \\
\hline Wrocław & 8057,60 & 8169,60 & 8536,98 \\
\hline Zielona Góra & 8294,20 & 8194,72 & 7470,00 \\
\hline
\end{tabular}

Źródło: Opracowanie własne na podstawie danych uzyskanych od dyrektorów izb administracji skarbowej w trybie ustawy o dostępie do informacji publicznej przez T. Ludwińskiego (Przewodniczącego Rady Krajowej Sekcji Administracji Skarbowej NSZZ „Solidarność”).

Warto zauważyć, że zgodnie z projektem uchwały Rady Ministrów z dnia 5 stycznia 2021 r. zmieniającej uchwałę w sprawie ustanowienia programu wieloletniego Modernizacja Krajowej Administracji Skarbowej w latach 2020-2022 proponuje się wprowadzenie zmian polegających na zmniejszeniu środków w latach 2020-2022, tj. w: priorytecie I, z kwoty 880000 zł do kwoty 694293 zł (łącznie o kwotę 185707 zł) ${ }^{102}$. Uzasadnia się to tym, że w 2021 r. zrezygnowano z realizacji podwyżek wynagrodzeń i uposażeń z pochodnymi oraz realizacji dodatków zadaniowych i specjalnych w łącznej kwocie 171866 tys. zł w związku z decyzją

102 https://archiwum.bip.kprm.gov.pl/kpr/form/rejestr17229433918,dok.html; https://www.infosecurity24.pl/sluzby-mundurowe/uchwala-modernizacyjna-kas-do-zmianyw-tym-roku-bez-podwyzek (dostęp: 5.03.2021 r.). 
o zamrożeniu funduszu płac w sferze budżetowej. Zatem w 2022 r., w konsekwencji braku realizacji podwyżek wynagrodzeń/uposażeń z pochodnymi w 2021 r., odstąpiono od wypłaty dodatkowego wynagrodzenia rocznego/nagrody rocznej wraz $\mathrm{z}$ pochodnymi $\mathrm{w}$ łącznej kwocie 13841 zł $^{103}$. Przykładowo w 2021 r. „z podstaw zasiłków, zarówno liczonych teraz, jak i wcześniej (tj. macierzyńskich/chorobowe, w tym też ciążowe/rehabilitacje/opieki), został wyłączony składnik jakim są nagrody. Jest to tzw. «składnik utracony», który został wyłączony w oparciu o przepisy dotyczące m.in. braku funduszu nagród”104.

\section{Podsumowanie}

Poczynione ustalenia związane z wprowadzeniem do polskiego sytemu podatkowego Krajowej Administracji Skarbowej wraz z całym „bagażem jej mankamentów” potwierdzają konstatację B. Brzezińskiego, zgodnie z którą „w jednym z państewek starożytnej Grecji inicjator zmian ustawodawczych zanim wystąpił ze stosownym projektem, wchodził na stołek i zakładał na szyję pętlę sznura przymocowanego drugostronnie do gałęzi drzewa. To, czy pozwolono mu zejść ze wspomnianego wyżej stołka, zależało od jakości projektu, jaki publicznie przedstawiał. Niestety, ta wartościowa praktyka pierwszego (a niekiedy i ostatniego) czytania została z czasem zaniedbana, czego skutki w sposób jaskrawy widoczne są we współczesnej legislacji dotyczącej podatków” ${ }^{105}$, a także w „dysfunkcjach” kadrowo-płacowych w przypadku Krajowej Administracji Skarbowej. W piśmiennictwie zadaje się także pytanie: czy zgodnie z tradycją chrześcijańską tzw. siedem grzechów głównych wystarczy, aby zdiagnozować „uchybienia” dzisiejszej legislacji ${ }^{106}$, w tym także podatkowej? Według A. Kidyby należy jeszcze pamiętać o ósmym grzechu - znanym we wschodnim chrześcijaństwie - jako „acedia”, czyli traktowanie jako

103 Tamże.

104 T. Ludwiński, Kolejne sankcje dla zatrudnionych w KAS, https://www.skarbowcy.pl/blaster/ extarticle.php?show=article\&article_id=27728 (dostęp: 10.05.2021 r.).

105 B. Brzeziński, Prawo podatkowe. Zagadnienia teorii i praktyki, Toruń 2017, s. 334.

106 A. Kidyba, Osiem..., s. D2. 
zwyczajnego czegoś, do czego powinno się czuć niechęć ${ }^{107}$. Przekładając ten „grzech” na grunt polskiej legislacji, wydaje się, że jest nim dziś „wypadkowa” tzw. obłudy polityczno-legislacyjnej wraz z chuligaństwem prawnym i serwilizmem ${ }^{108}$.

Mając na względzie m.in. zasadę przyzwoitej legislacji, składającą się na konstrukcję państwa prawnego, należy zauważyć, że także tzw. polityka kadrowo-płacowa w strukturze Krajowej Administracji Skarbowej związana z obsadzaniem wszystkich stanowisk, nawet najniższego szczebla, powinna mieć transparentny charakter ${ }^{109}$, a nie pozorowany $\mathrm{z}$ agonią służby cywilnej $\mathrm{w}$ tle ${ }^{110}$. Trafności powyższych konkluzji potwierdza chociażby trzyletni limit mianowań urzędników służby cywilnej na lata 2021-2023, który wynosi odpowiednio: 2021 r. - 30 osób; 2022 r. - 40 osób; 2023 r. - 40 osób ${ }^{111}$, co de facto świadczy o dalszym „demontażu” służby cywilnej ${ }^{112}$. I chyba też m.in. dlatego wśród członków korpusu służby cywilnej powstał pomysł wysyłania do premiera listów z ziarenkami ryżu jako symbolu tego, że mają pracować za miskę ryżu ${ }^{113}$.

\section{Bibliografia:}

Batko-Tołuć K., Warto stać po właściwej stronie, https://informacjapubliczna.org/ news/warto-stac-po-wlasciwej-stronie/.

Brzeziński W., Nykiel W., Reforma systemu podatkowego - aspekty prawne, „Przegląd Podatkowy” 2003, nr 6, s. 3-9.

107 Tamże, s. D2-D3.

108 Tamże, s. D3.

109 Por. K. Falandys, P. Łabuz, H. Fedewicz, Nieunikniona reforma służb specjalnych Rzeczpospolitej Polskiej - propozycje de lege ferenda, „Zeszyty Naukowe Państwowej Wyższej Szkoły Techniczno-Ekonomicznej im. ks. Bronisława Markiewicza w Jarosławiu” 2020, nr 16, w druku.

110 Por. J. Itrich-Drabarek, Apolityczność jako czynnik profesjonalizacji służby cywilnej [w:] A. Dębicka, M. Dmochowski, B. Kudrycka (red.), Profesjonalizm w administracji publicznej, Białystok 2004, s. 267 i n.

111 https://www.gov.pl/web/premier/trzyletni-plan-limitu-mianowan-urzednikow-wsluzbie-cywilnej-na-lata-2021-2023 (dostęp: 10.03.2021 r.)

112 R. Barabasz, [w:] A. Radwan, Rzq̨d zamraża awanse i dodatki, „Dziennik Gazeta Prawna” z dnia 14 stycznia 2021 r., nr 8 (5416), s. B8.

113 A. Radwan, Urzędnicy nie chcq pracować za miskę ryżu i piszq do premiera, „Dziennik Gazeta Prawna” z dnia 8 grudnia 2020 r., nr 239 (5392), s. B9. 
Brzeziński B., Nykiel W., Stan prawa podatkowego w Polsce. Raport 2010, „Kwartalnik Prawa Podatkowego” 2011, nr 1, s. 62-83.

Brzeziński B., Prawo podatkowe. Zagadnienia teorii i praktyki, TNOiK, Toruń 2017.

Barabasz R. [w:] A. Radwan, Rzq̨d zamraża awanse i dodatki, „Dziennik Gazeta Prawna” z dnia 14 stycznia 2021 r., nr 8 (5416), s. B8.

Dróżdż W., Jak i po co powstała Krajowa Administracja Skarbowa? W czym pomaga przedsiębiorcom?, https://opoka.news/jak-i-po-co-powstalakrajowa-administracja-skarbowa-w-czym-pomaga-przedsiebiorcom.

Falandys K., Łabuz P., Fedewicz H., Nieunikniona reforma służb specjalnych Rzeczpospolitej Polskiej - propozycje de lege ferenda, „Zeszyty Naukowe Państwowej Wyższej Szkoły Techniczno-Ekonomicznej im. ks. Bronisława Markiewicza w Jarosławiu” 2020, nr 16, w druku.

Gajewski D.J., Nowak-Far A., Krajowa Administracja Skarbowa - propozycja konsolidacji aparatu skarbowego a uszczelnienie systemu podatkowego, „Analizy i Studia CASP” 2016, nr 2, s. 1-9.

Godusławski B., Exodus z Ministerstwa Finansów, „Dziennik Gazeta Prawna” z 9 marca 2020 r., nr 47 (5200), s. A12.

Gomułowicz A., Konstytucyjny aspekt stanowienia obowiq̨zów podatkowych [w:] M. Bogucka (red.), Finanse publiczne a Konstytucja, Poltext, Warszawa 2020.

Halicki A., Służba w służbie celno-skarbowej, BW, Szczecin 2021.

Itrich-Drabarek J., Apolityczność jako czynnik profesjonalizacji służby cywilnej [w:] A. Dębicka, M. Dmochowski, B. Kudrycka (red.), Profesjonalizm w administracji publicznej, SEAP, Białystok 2004.

Kacprzak I., Zawadka G., Jak żona komendanta CBŚP została głównym ekspertem skarbowym, https://www.rp.pl/Spoleczenstwo/311029933-Jak-zonakomendanta-CBSP-zostala-glownym-ekspertem-skarbowym.html.

Kidyba A., Osiem grzechów głównych, „Dziennik Gazeta Prawna” z dnia 16 lutego 2021, nr 31 (5439), s. D2-D3.

Kulicki J., Koncepcja Krajowej Administracji Skarbowej w świetle problemów administracji danin publicznych w Polsce, „Analizy i Studia CASP” 2016, nr 2, s. 10-39.

Leśniak G.J., Służby w administracji - sposób na wyższq emeryturę, https://www.prawo.pl/kadry/funkcjonariusze-sluzb-oddelegowani-alboemerytowani-zajmuja,506164.html.

Ludwiński T. [w:] A. Radwan, Urzędnik w mundurze wciq̨ż zarabia więcej, „Dziennik Gazeta Prawna” z dnia 25 lutego 2021 r., nr 38 (5446), s. B7. 
Ludwiński T., Kolejne sankcje dla zatrudnionych w KAS, https://www.skarbowcy.pl/ blaster/extarticle.php?show=article\&article_id=27728.

Łączkowski W., Wymiar sprawiedliwości a stosowanie prawa [w:] A. Dębiński, A. Grześkowiak, K. Wiak (red.), Ius et lex. Księga pamiq̨tkowa ku czci prof. Adama Strzembosza, KUL, Lublin 2002.

Łączkowski W., Prawo naturalne a prawo stanowione. Uwagi prawnika, „Ethos” 1999, nr 1-2, s. 173-182.

Melezini A., Teszner K. (red.), Krajowa Administracja Skarbowa. Komentarz, Wolters Kluwer, Warszawa 2018.

Modzelewski W., Czy podatnicy, zwłaszcza będący przedsiębiorcami, maja (choć trochę) zaufania do prawa podatkowego?, https://gf24.pl/26376/czypodatnicy-zwlaszcza-bedacy-przedsiebiorcami-maja-choc-troche-zaufaniado-prawa-podatkowego/.

Nowak I., Funkcjonariusze celni w strukturze Krajowej Administracji Skarbowej - uwagi wybrane, „Kwartalnik Prawa Podatkowego” 2019, nr 2, s. 37-56.

Nowak I., Dominiak M., Krajowa Administracja Skarbowa a uszczelnianie systemu podatkowego - spostrzeżenia po dwóch latach funkcjonowania [w:] P. Łabuz, I. Malinowska, M. Michalski (red.), Przestępczość gospodarcza. System zwalczania. Cz. 1, Difin, Warszawa 2020.

Nowak I., National Revenue Administration - current organisational and financial problems, „Prawo Budżetowe Państwa i Samorządu” 2020, nr 2, s. 3765, DOI: http://dx.doi.org/10.12775/PBPS.2020.010.

Nowak I., Krajowa Administracja Skarbowa w liczbach, „Kazus Podatkowy” 2020, nr 4, s. 24-25.

Nykiel W., Prawa podatnika a stanowienie prawa podatkowego - wybrane zagadnienia, „Kwartalnik Prawa Podatkowego” 2019, nr 4, s. 9-19.

Nykiel W., Sęk M., Karta Praw Podatnika - potrzebny instrument ochrony praw polskiego podatnika [w:] P. Borszowski (red.), Regulacje prawa finansów publicznych i prawa podatkowego. Podsumowanie stanu obecnego i dynamika zmian. Księga jubileuszowa dedykowana Profesor Wiesławie Miemiec, Wolters Kluwer, Warszawa 2020.

Piotrowski M., Ocena przeprowadzonej reformy zwiqzanej z utworzeniem Krajowej Administracji Skarbowej w świetle zasad tworzenia prawa i ochrony praw pracowniczych, listopad $2018 \mathrm{r}$.

Radwan A., Urzędnicy nie chcq pracować za miskę ryżu i piszq do premiera, „Dziennik Gazeta Prawna” z dnia 8 grudnia 2020 r., nr 239 (5392), s. B9.

Szpotański J., Gnom. Caryca. Szmaciak, LTW, Łomianki 2014. 
Ireneusz Nowak

Szwast M., Ocena przeprowadzonej reformy zwiqzanej z utworzeniem Krajowej Administracji Skarbowej w świetle zasad tworzenia prawa i ochrony praw pracowniczych, 15 września 2018 r.

Teszner K., Customs and Fiscal Control in Poland as a Radical Measure to Eliminate Tax Evasion, „Intertax” 2020, Vol. 48, Issue 10, s. 922-928. 